\title{
Cor Triloculare
}

National Cancer Institute

\section{Source}

National Cancer Institute. Cor Triloculare. NCI Thesaurus. Code C124589.

A cong enital anatomic anomaly in which the heart has only three chambers. 